\title{
PARTISIPASI MASYARAKAT DAN PERAN PENDAMPING DALAM PEMBERDAYAAN KELOMPOK USAHA BERSAMA (KUBE) MELATI 3 DI KELURAHAN GALUR
}

\author{
Nazera Nur Utami \\ Ilmu Kesejahteraan Sosial, FISIP Universitas Indonesia, nazera.nur@ui.ac.id
} Sari Viciawati Machdum

Ilmu Kesejahteraan Sosial, FISIP Universitas Indonesia, sari.viciawati@ui.ac.id

\begin{abstract}
ABSTRAK
Permasalahan sosial yang dihadapi masyarakat adalah kemiskinan yang menyebabkan ketimpangan kelompok masyarakat. Untuk meningkatkan taraf hidup masyarakat miskin, pemerintah melakukan pemberdayaan masyarakat pada program kelompok usaha bersama (KUBE). Salah satunya adalah KUBE Melati 3 yang terletak di Kecamatan Johar Kelurahan Galur Jakarta Pusat. Hasil penelitian menunjukkan partisipasi aktif dari anggota KUBE dan peranan pendamping. Partisipasi anggota digambarkan dalam mewujudkan keterampilan usaha kelompok, harapan membangun kelompok, berkolaborasi dalam pengambilan keputusan, menyumbangkan ide secara musyawarah, mengelola pemberian makanan tambahan (PMT), mengikuti perlombaan, dan iuran. Selanjutnya, pendamping KUBE Melati 3 melakukan peran fasilitatif, edukasional, representatif, dan peran teknik dalam upaya pemberdayaan. Penelitian ini menggunakan pendekatan kualitatif dengan jenis penelitian deskriptif. Wawancara mendalam dilakukan terhadap 10 orang informan yang dipilih melalui teknik purposive sampling.
\end{abstract}

KATA KUNCI: partisipasi masyarakat; peran pendamping; pemberdayaan.

\section{ABSTRACT}

The social problem faced by the community is poverty which causes inequality in community groups. The government has conducted community empowerment in the joint business group program to improve the standard of living of the poor. One of them is KUBE Melati 3 which is located in Johar District, Galur Village, Central Jakarta. The results showed that the participation of KUBE members and the role of companion. Member participation is described in the involvement of realizing group business skills, the hope of building groups, decision making collaboration, contributing ideas through deliberation, managing supplementary feeding, competitions, and financial contributions. And the companion roles is facilitative, educational, representative, and technical role in empowerment efforts. This research was conducted using a qualitative approach with descriptive research type. In-depth interviews were conducted with 10 informants who were selected through purposive sampling technique.

KEYWORDS: society participation; companion role; empowerment. 


\section{LATAR BELAKANG MASALAH}

Kemiskinan merupakan salah satu masalah sosial yang selalu hadir di tengah-tengah masyarakat di negara berkembang. Kemiskinan adalah akar permasalahan hilangnya martabat dan keadilan manusia, belum tercapainya masyarakat madani, tidak berjalannya demokrasi dan terjadinya degradasi lingkungan (Faturochman, 2007). Individu yang hidup dalam kemiskinan sangat rentan terhadap kejadian buruk yang ada di luar kendalinya.

Tingkat kemiskinan di provinsi DKI Jakarta pada tahun 2019 secara nasional merupakan provinsi yang terendah jika dibandingkan dengan 34 provinsi di Indonesia. Presentase penduduk miskin di provinsi DKI Jakarta pada September 2019 sebesar 3,42 persen atau sejumlah 362,30 ribu orang. Jika dibandingkan pada bulan Maret 2019, presentase penduduk miskin sebesar 3,47 persen atau 365,55 ribu orang. Total penduduk miskin berkurang sebesar 3,25 ribu orang atau turun 0,05 persen jika dibandingkan pada maret 2019. Angka ini adalah yang terendah dalam kurun waktu lima tahun terakhir.

Provinsi DKI Jakarta merupakan provinsi yang presentasi masyarakat miskin terbanyak pada Maret 2020 apabila dibandingkan dengan provinsi lainnya (wilayah yang menjadi lokasi penelitian). Kemiskinan dan ketimpangan yang terjadi karena tekanan ekonomi akibat pandemi virus Covid-19 sebab pandemi membuat pemerintah harus mengurangi aktivitas masyarakat perusahan dari berbagai lini sektor. Kenaikan tingkat kemiskinan di provinsi DKI
Jakarta, Jawa Barat dan Banten pasalnya mayoritas masyarakat di tiga wilayah ini bekerja sebagai buruh. Banyak Buruh yang mengalami PHK. Perusahan di sektor manufaktur mengalami tekanan hebat sehingga membuat perusahaan tidak bisa melakukan ekspansi sehingga perusahan dengan berat hati harus merumahkan karyawan (PHK). Banyaknya masyarakat yang terkena PHK (Pemutusan Hubungan Kerja) juga menjadi salah satu penyebab melonjaknya kemiskinan pada Maret 2020 di DKI Jakarta. Kota-kota besar seperti DKI Jakarta juga bergantung pada sektor Jasa. Jasa-jasa ini banyak di sektor pekerja informal. Jasa akan bergantung dengan konsumsi masyarakat, apabila konsumsi turun maka sektor jasa akan jatuh juga. Pandemi Covid-19 juga membuat daya beli masyarakat menurun. Akibatnya permintaan diseluruh sektor juga menurun.

Menurut Perpu Nomor 1 Tahun 2020 menyatakan bahwa pandemi Covid-19 (virus Corona) berdampak pada perlambatan pertumbuhan ekonomi nasional, penurunan penerimaan negara, peningkatan belanja negara dan pembiayaan, serta penurunan berbagai kegiatan ekonomi domestic sehingga perlu dimitigasi bersama dengan pemerintah dan Komite Stabilitas Sistem Keuangan (KSSK) untuk mengantisipasi dalam rangka menjaga stabilitas sektor keuangan. Untuk mengurangi resiko terburuk yang akan terjadi di masa pandemi Covid-19, pemerintah telah melakukan beberapa langkah-langkah antisipasi yaitu pemerintah melakukan penyelamatan di bidang kesehatan dan perekonomian nasional, jaring 
pengaman sosial (social safety net), pemulihan perekonomian serta untuk dunia usaha dan masyarakat yang terdampak Covid-19.

Mengingat jumlah penduduk miskin yang banyak di Pulau Jawa khususnya di Provinsi DKI Jakarta maka salah satu upaya y ang dapat dilakukan adalah dengan melakukan pemberdayaan masyarakat. Dalam kondisi pandemi seperti ini diperlukan usaha-usaha untuk menggenjot sektor ekonomi menjadi lebih baik salah satunya adalah mendukung kegiatan pemberdayaan program KUBE. Dengan Adanya program KUBE bisa membantu untuk menggerakkan perekonomian masyarakat khususnya masyarakat di DKI Jakarta. Pemerintah pada saat ini telah banyak melakukan pembaharuan dan membuat beberapa program pemberdayaan masyarakat miskin untuk meningkatkan taraf hidup masyarakat. Sasaran dari program pemberdayaan sendiri ialah masyarakat yang dinilai lemah dalam bidang ekonomi, sosial maupun politik.

Kementerian Sosial RI telah merancang dan mengimplementasikan beberapa program Pemberdayaan masyarakat. Salah satu program unggulan Kementerian Sosial yang membutuhkan partisipasi masyarakat dan untuk mengentas kemiskinan adalah program Usaha Ekonomi Produktif (UEP) dalam bentuk Kelompok Usaha Bersama (KUBE), yang bertujuan untuk memberdayakan kelompok masyarakat miskin dengan pemberian modal usaha melalui program Bantuan Langsung Pemberdayaan Sosial (BLPS) untuk mengelola Usaha Ekonomi Produktif (UEP). Kelompok Usaha Bersama Fakir Miskin
(KUBE-FM) adalah himpunan dari keluarga yang tergolong miskin dengan keinginan dan kesepakatan bersama membentuk suatu wadah kegiatan, tumbuh dan berkembang atas dasar prakarsa sendiri, saling berinteraksi antara satu dengan yang lain, dan tinggal dalam satuan wilayah tertentu dengan tujuan untuk meningkatkan produktivitas anggotanya, meningkatkan relasi sosial yang harmonis, memenuhi kebutuhan anggota, memecahkan masalah sosial yang dialaminya, menjadi wadah pengembangan usaha bersama dan dapat meningkatkan motivasi warga untuk lebih maju secara ekonomi dan sosial.

Penelitian terdahulu terkait program KUBE banyak membahas tentang pendampingan (Wulandari, 2011), efektivitas program KUBE (Mustafa, 2015), pemberdayaan masyarakat (Imron, dkk, 2014., Nasmi \& Maani, 2019., dan Indrika, 2013), pemberdayaan ekonomi (Yasin, 2015., dan Pratiwi, 2014), implementasi Kinerja KUBE (Widayanti \& Hidayatulloh, 2015), implementasi program KUBE (Mantiri, 2016., dan Imaduddin, dkk, 2016), implementasi kebijakan penanggulangan kemiskinan (Djunaedi, 2013., dan Sugiana, 2012). Selanjutnya penelitian terdahulu terkait partisipasi masyarakat banyak membahas tentang partisipasi masyarakat dalam program KUBE (Embanaras \& Rosdiana, 2016., dan Azhari, 2015), partisipasi masyarakat dalam penyelenggaraan KUBE (Usmaniya, 2014), partisipasi anggota kelompok dalam pengelolaan KUBE sektor perikanan (Ernawati, 2014), partisipasi masyarakat dalam pengelolaan dana 
desa (Tumbel, 2017), partisipasi masyarakat dalam perencanaan pembangunan (Purnamasari, 2011), partisipasi masyarakat dalam pembangunan (Asnar, 2016., dan Ripai, 2013).

Penelitian terdahulu tersebut dapat disimpulkan bahwa program KUBE telah memberikan manfaat khususnya dalam aspek ekonomi. Tetapi masih banyak kekurangan dalam pelaksanaanya khususnya dalam monitoring kegiatan tidak maksimal berjalan, kegiatan pendampingan juga belum maksimal, kualitas SDM dari pendamping dan anggota KUBE masih rendah, rendahnya partisipasi anggota dan pendamping pada program. Kemudian solusi yang dapat digunakan adalah melakukan sosialisasi, lebih banyak membuat kegiatan pelatihan yang bertujuan untuk meningkatkan kualitas sumberdaya manusia dan yang paling penting unsur keberhasilan dalam suatu program adalah adanya partisipasi yang baik di dalam setiap pihak yang terlibat dalam program. Partisipasi yang baik ini dapat terwujud jika ada rasa kerjasama dan gotong royong antar anggota serta pengurus KUBE agar kegiatan KUBE dapat berjalan sesuai dengan tujuan yang diharapkan. Kemudian jika semua pihak terkait program memiliki tingkat partisipasi yang baik maka tujuan program akan tercapai dan semua pihak tersebut akan mendapat manfaat dari program.

Salah satu wilayah yang menerapakan program KUBE yaitu Kelurahan Galur Jakarta Pusat. Di daerah tersebut terdapat KUBE Melati 3 yang terletak di Kecamatan Johar Kelurahan Galur Jakarta Pusat, KUBE Melati 3 ini adalah KUBE yang mendapatkan prestasi yaitu mendapatkan juara 2 KUBE Berprestasai tingkat DKI Jakarta tahun 2019 dan Pendamping KUBE Melati 3 mendapatkan juara 1 Pendamping Berprestasi tingkat DKI Jakarta tahun 2019. Adanya keberhasilan yang dimiliki oleh KUBE Melati 3 tersebut secara otomatis menunjukkan bahwa terdapat partisipasi yang aktif dalam diri anggota dan pihak-pihak yang terkait pada anggota KUBE. Berdasarkan penjelasan mengenai penelitian terdahulu dan adanya prestasi yang dimiliki oleh KUBE Melati 3 maka sangat menarik dibahas lebih dalam menggunakan metode kualitatif agar hasilnya lebih tajam terkait kondisi partisipasi anggota dan pendamping pada program KUBE dan peran pendamping KUBE Melati 3 membuat anggota KUBE berpartisipasi aktif dalam program KUBE. Kemudian penelitian mengenai kondisi partisipasi yang ada pada KUBE juga dalam kurun waktu sepuluh tahun terakhir juga masih sangat minim yaitu hanya ada 3 penelitian dalam kurun waktu tersebut.

Kelompok Usaha Bersama (KUBE) Melati 3 di Kelurahan Galur dibentuk oleh Dinas Sosial DKI Jakarta pada tahun 2016. KUBE Melati 3 menjalankan kegiatan pemberdayaan secara swadaya atau mandiri, tidak mendapatkan bantuan modal sama sekali dari pemerintah setempat maupun bantuan modal dari pemerintah pusat. KUBE ini beranggotakan 10 orang yang mempunyai usaha ekonomi produktif (UEP) yang sejenis yaitu dibidang kuliner. KUBE Melati 3 memiliki 1 pendamping KUBE yang bernama ibu Sri Nurani Maftuhah (Nunung/N). KUBE Melati 3 bergerak dibidang Catering makanan, 
pembuatan kue-kue basah dan kue kering. Pilihan produksi tersebut disepakati bersama berdasarkan pertimbangan yang meliputi (a) kemampuan dan pengalaman anggota, (b) adanya kebutuhan pasar, dan (c) lokasi kedekatan dengan pasar tradisional. Mayoritas anggota KUBE Melati 3 mempunyai usaha ekonomi produktif (UEP) dan hanya beberapa yang tidak mempunyai UEP karena berstatus ibu rumah tangga. UEP meliputi usaha nasi uduk, warung klontong, pedagang lauk-pauk, catering makanan, stik keju, keripik bawang, peyek, bir pletok, susu jahe, kue nastar dan beberapa kue-kue basah lainnya.

Menjalankan kegiatan pemberdayaan secara mandiri tidak membuat anggota KUBE Melati 3 dan pendamping menjadi putus asa. Mereka bergotong-royong menjalankan kegiatan pemberdayaan hingga sekarang. Menurut informasi yang didapatkan dari pendamping KUBE Melati 3 bahwa, hasil-hasil produk KUBE dipasarkan bersama-sama oleh anggota KUBE ke warung-warung dan pesanan online (melalui aplikasi whatsapp dan facebook), melalui cara pemasaran manual dengan pemberian sample kue kering maupun kue basah misalnya nastar, kastangel dan lainnya dan mengikuti kegiatan bazar di kelurahan Galur dan di Kecamatan Johar Baru. Hasil dari penjualan produk KUBE dibagi rata tiap anggotanya dan sebagian dipergunakan untuk tambahan uang kas KUBE. Beberapa anggota KUBE pernah berpartisipasi mengikuti beberapa pelatihan memasak membuat kue yang dibentuk oleh dinas sosial DKI Jakarta. Tujuan pelatihan ini adalah untuk meningkatkan keterampilan ibu-ibu anggota KUBE di kelurahan
Galur dalam membuat kue. Hasil yang didapatkan dari pelatihan adalah anggota KUBE mendapatkan beberapa peralatan memasak seperti beberapa panci, kuali dan sertifikat. Peralatan memasak yang didapatkan dari pelatihan disumbangkan kepada kelompok untuk tambahan alat-alat catering kelompok karena pada dasarnya anggota KUBE masih kekurangan perabotan alat-alat untuk memasak. KUBE Melati 3 juga menggunakan dana Iuran Kesetiakawanan Sosial (IKS) untuk membantu anggota kelompok yang mengalami musibah, sakit maupun keperluan mendesak anggota KUBE.

Selain itu, KUBE Melati 3 mendapatkan kesempatan untuk mengikuti perlombaan KUBE berprestasi tingkat DKI Jakarta pada tahun 2019. Perlombaan tersebut dilaksanakan selama 2 hari. KUBE Melati 3 Kelurahan Galur Kecamatan Johar Baru memenangkan juara 2 sebagai KUBE berprestasi tingkat DKI Jakarta dan Sri Nurani Maftuhah selaku Pendamping KUBE Melati memenangkan juara 1 sebagai pendamping KUBE berprestasi tingkat DKI Jakarta. KUBE Melati 3 mendapatkan hadiah berupa tropi, piagam dan uang pembinaan juara 2 sebesar $\mathrm{Rp}$. 9.100.000,- dan untuk pendamping berprestasi mendapkan hadiah berupa tropi, piagam dan uang pembinaan juara 1 sebesar Rp. 9.000.000.

Keberhasilan ini tentunya merupakan kebanggaan dan prestasi tersendiri bagi anggota KUBE dan kelurahan Galur. Prestasi ini tidak luput dari usaha setiap anggota KUBE yang bersama-sama menjalankan dan membangun KUBE ini dari 0 (nol) sampai menjadi KUBE berprestasi juara 2 tingkat DKI Jakarta sehingga 
berdampak positif untuk anggota KUBE. Anggota KUBE merasakan setelah menjadi juara 2 KUBE berprestasi berdampak secara sosial dan ekonomi pendampatan mereka. Banyak masyarakat yang menganggap mereka di lingkungan sosial, membeli produk-produk UEP anggota KUBE atau produk KUBE Melati 3 dan adanya perhatian lebih dari aparat kelurahan maupun aparat kecamatan. Anggota KUBE merasa perjuangan mereka selama ini tidak sia-sia walaupun pada prosesnya tidak mudah dan keberhasilan ini menjadikan semangat baru para anggota KUBE untuk menjadikan KUBE Melati 3 lebih terkenal dan sukses untuk kedepannya. Dalam proses kegiatan pemberdayaan KUBE menunjukkan bahwa partisipasi dari anggota KUBE sudah terlihat. Penelitian ini lebih membahas gambaran partisipasi anggota KUBE, serta peran pendamping KUBE secara mendalam dalam mewujudkan suatu pemberdayaan.

\section{METODE PENELITIAN}

Penelitian ini dapat memberikan gambaran mendalam mengenai partisipasi masyarakat dalam pemberdayaan melalui program KUBE Melati 3 Kelurahan Galur. Oleh karena itu penelitian ini menggunakan pendekatan kualitatif. Menurut Neuman (2013) menyatakan metode kualitatif adalah sebagai berikut:

"In a qualitative study, we rely more on the principles from interpretive or critical social science. We speak a language of "cases and contexts" and of cultural meaning. Our emphasis is on conducting detailed examinations of specific cases that arise in the natural flow of social life". Dari pernyataan diatas menerangkan bahwa di dalam kualitatif lebih mengandalkan prinsip dari Ilmu social interpretative atau kritis dan berbicara pada kasus dan konteks serta melakukan detail pemeriksaan kasus khusus yang muncul di kehidupan sosial.

Jenis penelitian yang digunakan dalam penelitian ini adalah penelitian deskriptif yang menjelaskan mengenai proses partisipasi masyarakat dalam pemberdayaan melalui program KUBE Melati 3 Kelurahan Galur. Pengumpulan data dilakukan pada bulan Mei 2020 - Agustus 2020, melalui studi literatur, observasi dan wawancara mendalam. Penelitian ini dilakukan di Kelurahan Galur Kecamatan Johar Baru Jakarta Pusat dengan Teknik pemilihan informan purposive sampling. Hal ini dimaksudkan dengan memilih informan yang merupakan anggota dan pendamping KUBE berprestasi tingkat DKI Jakarta Tahun 2019. Anggota KUBE yang dipilih berjumlah 10 orang, pendamping KUBE satu orang, kepala satuan pelaksana (KASAPEL) Kecamatan Johar Baru berjumlah satu orang, dan Kepala Seksi Penanganan Fakir Miskin Dinas Sosial DKI Jakarta berjumlah satu orang.

\section{HASIL DAN PEMBAHASAN}

Permensos No. 2 Tahun 2019 tentang Bantuan Sosial UEP Kepada KUBE untuk penanganan fakir miskin adalah upaya yang terarah, terpadu, dan berkelanjutan yang 
dilakukan pemerintah pusat, pemerintah daerah, dan masyarakat dalam bentuk kebijakan, program, kegiatan pemberdayaan, pendampingan, serta fasilitasi untuk memenuhi kebutuhan hidup. Partisipasi anggota dan peran pendamping KUBE Melati 3 dikatakan sebagai KUBE berprestasi karena menunjukkan berbagai aktivitas pemberdayaan dan peranan aktif pendamping dalam mendukung aktivitas tersebut.

1. Partisipasi anggota KUBE Melati 3 dalam pemberdayaan.

Partisipasi digambarkan sebagai keterlibatan anggota KUBE Melati 3 dalam menjalankan strategi pemberdayaan. Hal ini berupa keterlibatan mental dan emosi, serta keterlibatan fisik dengan segala kemampuan yang dimiliki. Secara mental, keterlibatan anggota KUBE dideskripsikan dengan bentuk penyadaran, inisitif, keinginan sumbangsih dan tanggung jawab dalam usaha-usaha mewujudkan pemberdayaan.

KUBE Melati 3 bermula dengan keterampilan usaha catering yang dimiliki salah satu anggota dan diinisiasi oleh pendamping KUBE. Seperti yang diungkapkan informan adalah:

"Awal mulanya kalau saya sama seperti teman-teman anggota yang lain. Sebenarnya sudah punya masing-masing usahaya, ada yang buat makanan macam-macam mereka produksi sendiri, dan kalau saya membuat catering dengan nama saya. Saya sebenarnya suka masak untuk pementasan theater di sini, terus akhirnya kami diikutkan pelatihan. Karena bu $N$ kan selaku pendamping, menyarankan untuk membentuk
KUBE. Akhirnya kami sepakat dengan membentuk KUBE Melati 3 dengan jenis usahanya yang berbeda-berda" (F/IRT/48/Ketua KUBE/12-07-2020).

Ketua KUBE Melati 3 menjelaskan bahwa rata-rata anggota memiliki keterampilan dan pelatihan usaha pada masing-masing produk makanan. Adanya inisiasi dari pendamping menghasilkan pembentukan kelompok usaha (KUBE) dengan tujuan memperoleh program stimulan dan meningkatkan kualitas hidup anggota KUBE. Kondisi tersebut sejalan dengan penjelasan dari Davis bahwa partisipasi merupakan keterlibatan mental dan emosional seseorang individu dalam situasi kelompok tertentu yang mendorongnya untuk mendukung atau menunjang tercapainya tujuan-tujuan kelompok serta ikut bertanggung jawab terhadapnya (Ndraha, 1994). Tujuan untuk meningkatkan kualitas hidup anggota KUBE Melati 3 sejalan dengan tujuan partisipasi yang dijelaskan oleh Mikkelsen (2005) yaitu partisipasi merupakan keterlibatan masyarakat dalam upaya pembangunan lingkungan, kehidupan dan diri mereka sendiri.

Secara fisik, anggota KUBE Melati 3 melakukan aktivitas persiapan, pelaksanaan, dan evaluasi terhadap program kegiatan KUBE yang menjadi misi dalam pemberdayaan kelompok.

1) Berpartisipasi dalam persiapan, identifikasi masalah dan potensi, dan perencanaan kegiatan.

Kegiatan persiapan untuk melaksanakan kegiatan dilakukan melalui pertemuan anggota kelompok KUBE Melati 3 dan pendamping setiap 
satu kali dalam seminggu. Pembahasan pada pertemuan kelompok terkait dengan kegiatan wajib mereka yaitu pemberian makanan tambahan (PMT) yang dilaksanakan setiap 2 kali dalam satu bulan, persiapan produksi makanan/catering dan strategi pemasarannya, persiapan dalam perlombaan KUBE prestasi, dan persiapan pada kegiatan lainnya yang dapat menunjang potensi anggota kelompok. Kesepakatan terkait kegiatan PMT juga diungkapkan oleh ketua KUBE yaitu:

"Setiap dua kali dalam satu bulan, kami membuat pemberian makanan tambahan (PMT) untuk balita, posbindu, dan lansia. Kami memanfaatkan pertemuan yang setiap minggu dilaksanakan untuk membahas proses pembuatan dan penyaluran PMT, dan membahas macammacam masalah lainnya” (F/IRT/48/Ketua KUBE/12-07-2020).

Pertemuan untuk membahas persiapan dan segala aktivitas untuk kebutuhan kelompok berlandaskan atas musyawarah bersama, seperti yang diungkapkan salah satu anggota KUBE Melati 3 yaitu:

"Kalau mengadakan pertemuan, kita sepakat dulu untuk bertemu di rumah siapa, Kemudian kita bahas macam-macam, kita musyawarakan tentang modal produk catering dan dijual dengan harga berapa. Hal ini kita musyawarahkan sama-sama, kalau tidak nantinya bingung masalah pendapatannya mau digunakan untuk apa. Selain itu, kami juga pernah merencanakan untuk membuat seragam kelompok yang didanai oleh kelurahan untuk kegiatan perlombaan dan kegiatan kelompok lainnya. Sebelum covid, kami memakainya saat lomba di gedung RPTRA. Tentang iuran kelompok juga kami musyawarkan bersama. Banyak hal yang kami bahas untuk kepentingan kelompok" (S/Pedagang/56/Anggota/12-072020).

Hasil musyawarah berupa jumlah makanan yang dibuat untuk kegiatan PMT, inovasi produk makanan pada perlombaan, iuran sejumlah Rp. 5000 (Lima Ribu Rupiah) setiap pertemuan untuk mengisi kas kelompok, seragam batik, dan hasil kesepakatan lainnya, termasuk dalam menghadapi hambatan atau masalah dalam kelompok.

Masalah yang dihadapi saat ini oleh KUBE Melati 3 adalah adanya penyebaran covid-19 yang mengharuskan anggota kelompok menunda pertemuan dan kegiatannya, masih ada anggota yang belum pernah mengikuti pelatihan, anggota yang mulai jarang mengikuti pertemuan karena urusan keluarga dan berdagang, serta permasalahan dalam penyaluran dana bantuan. Permasalahan yang dihadapi juga di musyawarahkan bersama untuk mencari solusi dan membuat keputusan. Ketua kelompok KUBE Melati 3 mengungkapkan bahwa:

"Ya, selama ini kan memang dari kelurahan sudah ada ijin buat aktivitas KUBE kami, pendamping dan anggota lainnya juga sudah mengusahakan dapat stimulan dari kelurahan. Alhamdulillah KUBE kami dipercayakan menjalankan kegiatan selama dua tahun, tapi karena ada covid-19 ya terhenti juga kegiatannya. Masalah lain ya masalah yang sering terjadi, kadang-kadang ada anggota yang 
sulit untuk ikut pertemuan. Menurut saya, selama itu tidak terlalu mengganggu ya tidak apa-apa. Selama ini anggota kelompok rata-rata saling membantu, dan yang tidak datang ke pertemuan tetap ikut pada hasil rapat dan membantu saat berkegiatan” (F/IRT/48/Ketua KUBE/12-072020).

\section{Berpartisipasi dalam menentukan} keputusan merupakan kepentingan utama dalam pertemuan kelompok. Hal ini menjadi strategi untuk menyelesaikan permasalahan yang ada. Dalam menentukan keputusan, kelompok KUBE Melati 3 berupaya untuk memahami situasi yang terjadi saat ini dan tetap menjalani usaha masingmasing hingga aktivitas KUBE dapat berlangsung dengan baik. Penyelesaian permasalahan internal dapat dikelola dengan kerjasama yang baik antar anggota kelompok. Hal ini sesuai dengan konsep yang dikemukakan oleh Mikkelsen (2005), bahwa salah satu unsur dalam partisipasi kelompok adalah adanya kolaborasi yang menunjukkan kontrol bersama atas pengambilan keputusan. Selain itu, kondisi tersebut termasuk dalam bentuk partisipasi yang dikemukakan oleh Chambers sebagai empowering process, bahwa KUBE Melati 3 mampu melakukan analisis masalah mereka, memikirkan bagaimana cara mengatasinya, mendapatkan rasa percaya diri untuk mengatasi masalah, mengambil keputusan tentang alternatif pemecahan masalah yang dipilih (Mikkelsen, 2005).

Adapun kegiatan pertemuan dalam melakukan persiapan kegiatan sejalan dengan pemikiran Hamijoyo dan Iskandar bahwa partisipasi dapat dilakukan dengan menyumbangkan buah pikiran dalam sebuah pertemuan atau pada saat rapat bersama secara musyawarah (Huraerah, 2011).

2) Berpartisipasi dalam pelaksanaan kegiatan.

Aktivitas yang dilakukan anggota KUBE Melati 3 dalam mewujudkan pemberdayaan sangat beragam berdasarkan kepentingan kelompok dan pribadi. Beberapa anggota juga merupakan para ibu kader di Kelurahan dalam membantu melaksanakan kegiatan sosial dan kesehatan yang rutin dilaksanakan setiap bulannya. Aktivitas tersebut diungkapkan oleh ketua kelompok yaitu:

"Kami aktif dalam kegiatan posbindu (pos bimbingan terpadu) yang pelayanannya dari usia 15 tahun sampai di atas lansia, bebaslah tapi batasannya minimal di umur 15, dan juga pos balita. Jadi kalau pos balita itu kan 2 pos, kalau posbindu sama lansia itu kan jadi satu. Kalau untuk lansia atau posbindu itu biasanya itu sih gak sering ada pemeriksaan kolesterol, ada juga pemeriksaan gula tapi gak rutin, yang rutin itu timbang berat badan, tensi,dan ukur lingkar perut. Kalau balita, yang membantu pihak kesehatan saat imunisasi, tinggi dan berat badan" (F/IRT/48/Ketua KUBE/12-07-2020).

Aktivitas rutin sebagai kader yang dilaksanakan merupakan strategi untuk melibatkan kegiatan KUBE Melati 3. Hal ini berupa kegiatan rutin dalam program pemberian makanan tambahan (PMT) pada aktivitas posbindu, gizi balita dan ibu hamil dengan jenis makanan sehat yang sudah ditentukan dari kelurahan setempat. Kegiatan PMT dilakukan 2 kali dalam satu bulan dengan ketentuan 2 minggu 
kegiatan posbindu, dan 2 minggu berikutnya kegiatan untuk balita dan ibu hamil. Seperti yang diungkapkan informan yaitu:

\section{"Pelaksanaan PMT Alhamdulillah}

lancar. Kegiatan dimulai dari jam 10 sampai jam 12. Kalau di RW 7 terdapat 2 pos balita dan 1 pos untuk lansia. Kalau kegiatan di RW selanjutnya menggunakan gedung interaksi. Lansia dan posbindu disatukan dalam gedung tersebut" D/IRT/46/Anggota KUBE/14-7-2020).

Adapun jumlah pembuatan makanan yang dilakukan oleh anggota KUBE juga dijelaskan oleh pendamping yaitu:

"Pemberian Makanan Tambahan atau kami biasa sebut dengan PMT itu untuk balita sama untuk posyandu lansia dan posbindu. Nah itu sebulan kami laksanakan. Tergantung, kalau posyandu kan ada posyandu balita 2 pos di RW 7 ya, berarti 2 kali, satu pos 100 box makanan, jadi 2 pos jadi 200 box, nah posbindu juga begitu, satu posbindu 120 orang terus lansianya 80 jadi untuk lansia sama posbindu jadi 200, totalnya 400 box makanan. Pengerjaannya 2 kali karena kan posbindu sama balita kan pisah jadwalnya, jadi begitu kasih Pemberian Makanan Tambahan menunya dari puskesmas, dananya dari kelurahan" (N/Guru Paud/51/Pendamping KUBE/12-7-2020).

Anggota KUBE Melati 3 dan pendamping menjelaskan tentang keterlibatan mereka untuk berpartisipasi pada program yang rutin dilaksanakan di kelurahan bersama petugas kesehatan. Mereka membuat makanan sehat dan bergizi untuk para lansia, balita dan ibu hamil setiap bulannya. Dukungan dari kelurahan juga dijelaskan oleh Kasapel KUBE yaitu:

"Sebenarnya di situasi normal sebelum Covid-19, banyak hal yang sebenarnya bisa dibantu. Kadang-kadang kita sering beli nasi penjualan KUBE Melati 3, diikutsertakan dalam PMT secara rutin, kebijakan lain juga kita mendorong dan mensuport mereka. Kemudian bantuan-bantuan juga ada, baik materil maupun support yang lain. Kayak pelatihan, itu suka ada. Di KUBE yang mana aja ya, dan kita kalau kelurahan kita suka mendorong kalau ada kebutuhan, kita pakai KUBE aja. Seperti itu kita manfaatkan resource KUBE itu untuk membuat apa saja, seperti itu sih yang kita berdayakan" (D/Kasapel/38/PNS Kec.Johar Baru/17-7-2020).

Sebelum adanya hambatan dari penyebaran virus Covid-19, aktivitas KUBE sangat banyak dari pihak kelurahan. Pemerintah juga antusias untuk menunjukkan dukungan bagi para KUBE khususnya KUBE Melati 3. Selain dari kegiatan PMT, KUBE Melati 3 juga menjual hasil usaha dalam bentuk catering kepada beberapa elemen masyarakat sebagai produk KUBE mereka. Adapun rutinitas pembuatan produk usaha mereka, dijelaskan oleh informan sebagai berikut:

"Kita bikin untuk catering dan khususnya di kegiatan PMT itu setiap pokok makanan 200 kotak, 2 pos posbindu dan balita 120 orang, kemudian ada 1 pos lansia 80 orang. Karena satu bulannya kegiatan kami 2 kali, makanya buat 400 box total dalam satu bulan. Prosesnya seperti biasa, kami ada yang pergi ke pasar, ada yang bagian masak juga seperti saya dan ibu-ibu lain 
masak nasi, masak sayurnya, dan macam-macam minimal 3 jenis makanan” (F/IRT/48/Ketua KUBE/12-07-2020).

Rata-rata anggota KUBE aktif untuk melakukan proses pembuatan catering untuk kegiatan di kelurahan. Mereka biasanya menyediakan susu, kue kering, pudding, mie basah, telur balado, telur kukus, sayuran bergizi, dan lainnya. Aktivitas lainnya diluar rutinitas adalah berpartisipasi dalam mengikuti kegiatan perlombaan dan bazar. Seperti yang dijelaskan oleh informan yaitu:

"Dulu KUBE kami sering ikut pameran di Kecamatan, biasa ikut bazar-bazar juga. Kami sering menyediakan bir pletok (minuman kesehatan), susu jahe, peyek, kue nastar, nasi bungkus dan lain-lain. Kalau bir pletok itu saya jual Rp 15.000 itu 2 botol, yang 250 ml. Tapi kalau di kantor suami kadang satu botol Rp 10.000, kalo di temen-temen Rp 15.000 dua botol gitu ya, bazar-bazar juga Rp 15.000, kalau peyek kami jual Rp. 10.000 sudah dapat banyak di bazar makanya cepat laku” (J/Pedagang/36/Sekretaris KUBE/13-7-2020).

Anggota KUBE Melati 3 juga aktif berpartisipasi dalam kegiatan bazaar untuk menjual produk KUBE mereka. Selain itu, produk makanan tersebut menjadi juara kedua pada perlombaan KUBE berprestasi. Selain dari pelaksanaan produk usaha, KUBE Melati 3 juga berpartisipasi dalam mengadakan iuran bersama yang telah disepakati pada saat pertemuan. Ketua KUBE Melati 3 menjelaskan bahwa:

"Kami sepakat mengadakan iuran setiap pertemuannya yaitu Rp. 5000 (lima ribu rupiah) setiap anggotanya. Uangnya biasanya kami gunakan untuk keperluan kelompok jika kehabisan suport dana untuk membeli barangbarang catering kami. Selain itu digunakan untuk membantu anggota kami yang sakit, dan juga untuk keperluan mendadak lainnya untuk kepentingan bersama. Ya kami saling membantu dan memanfaatkan uang kas sebaik-baiknya" (F/IRT/48/Ketua KUBE/12-07-2020).

Para anggota KUBE sepakat dan berpartisipasi untuk melakukan iuran kas kelompok saat mengadakan pertemuan. Inisiatif tersebut tidak dipaksakan, namun semua anggota tidak merasa terbebani terkait iuran kas kelompok. Dana tersebut juga digunakan untuk kepentingan usaha kelompok dan membantu anggota jika ada yang kesusahan sesuai pada situasi permasalahan yang dihadapi. Bendahara yang ditunjuk juga mampu mengelola keuangan tersebut dengan baik. Hingga saat ini tidak terdapat permasalahan terkait iuran kas kelompok. Hal ini merupakan salah satu bentuk partisipasi kelompok untuk memanfaatkan aset finansial sesuai kesepakatan bersama dalam keperluan kelompok.

Aktivitas pada program PMT oleh KUBE Melati 3 merupakan makna partisipasi yang dikemukakan oleh Mikkelsen (2005) yaitu proses membuat masyarakat menjadi lebih peka dalam rangka menerima dan merespon berbagai proyek pembangunan. Kemudian didukung oleh konsep partisipasi aktif yang bermakna bahwa orang ataupun kelompok yang sedang ditanyakan mengambil inisiatif dan mempunyai otonomi untuk melakukan hal itu. Rutinitas kegiatan PMT 
dapat menumbuhkan rasa tanggung jawab pada KUBE Melati 3. Sebagaimana yang dijelaskan oleh Histiraludin bahwa Partisipasi lebih merupakan alat pada keterlibatan masyarakat secara aktif dalam keseluruhan proses kegiatan sebagai media penumbuhan kohesifitas antar masyarakat, masyarakat dengan pemerintah menggalang tumbuhnya rasa memiliki dan tanggung jawab pada program yang dilakukan (Handayani, 2006).

Selanjutnya, kegiatan bazar dan perlombaan merupakan partisipasi dalam menunjukkan keterampilan dan kemahiran yang diberikan perorangan/kelompok untuk mendorong aneka ragam usaha (Hamijoyo dan Iskandar dalam Huraerah, 2011).

Huraerah (2008) juga menjelaskan tentang pembagian macam-macam partisipasi. Salah satunya adalah partisipasi dalam bentuk iuran uang atau barang dalam kegiatan partisipatori. Dana dan sarana sebaiknya datang dari dalam masyarakat itu sendiri. Keterkaitan pada konsep ini, ditunjukkan pada partisipasi anggota KUBE Melati 3 dalam melaksanakan iuran kas kelompok sebanyak Rp.5000,- dalam setiap pertemuan untuk digunakan sebaik-baiknya pada kebutuhan dan kepentingan kelompok.

3) Memiliki harapan dalam pemberdayaan.

Harapan merupakan salah satu bentuk keterlibatan mental dan emosi dari seseorang di dalam situasi kelompok yang mendorong mereka untuk menyokong kepada pencapaian tujuan dan nantinya akan ikut bertanggung jawab terhadap kelompoknya (Santoso dalam Dwiningrum, 2011). Dengan adanya harapan pada rasa sense of belongines terhadap tujuan pemberdayaan, akan menimbulkan rasa ingin berpartisipasi aktif untuk meningkatkan kualitas hidup kedepannya.

Harapan dari anggota KUBE Melati 3 menunjukkan tentang kemajuan dan dukungan kegiatan kelompok. Diantaranya adalah harapan untuk dapat mengembangkan produk usaha catering agar banyak yang membeli dan investasi pada kegiatan mereka, mendapatkan dukungan modal, dan bantuan program lainnya dari pemerintah maupun swasta.

Selanjutnya, mereka juga berharap agar KUBE Melati 3 tetap eksis dalam masyarakat dan produk usaha mereka juga tetap diterima di Kelurahan dan Kecamatan dan semakin banyak pihak yang mempercayakan catering mereka pada rutinitas program masyarakat.

2. Peran pendamping KUBE Melati 3 dalam pemberdayaan.

Dalam Permensos No. 2 Tahun 2019 pada pasal 9 menjelaskan bahwa pendamping sosial KUBE memiliki tugas dalam membentuk KUBE, memverifikasi calon penerima bantuan, menyiapkan calon penerima bantuan, menyiapkan rencana anggaran biaya, memberikan bimbingan teknis kepada KUBE, memberikan bimbingan motivasi sosial, mendampingi pelaksanaan UEP yang dilaksanakan oleh KUBE, memantau pelaksanaan kegiatan; dan/atau membantu dalam penyusunan laporan kegiatan. Aktivitas tersebut juga dilakukan oleh pendamping KUBE Melati 3 dalam pemberdayaan, bahkan peran pendamping dapat memajukan KUBE Melati 3 menjadi KUBE berprestasi tingkat provinsi DKI Jakarta. 
Beberapa aktivitas peranan yang dilakukan adalah:

1) Melakukan pendekatan dan membangun kepercayaan kepada anggota KUBE.

Sebelum berfokus pada kegiatan KUBE, pendamping perlu membangun kepercayaan antar anggota untuk memperoleh kesepakatan bersama. Dalam membangun kepercayaan, pendamping KUBE Melati 3 melakukan pendekatan yang mulanya tidak mudah kepada para anggota KUBE dikarenakan pola pikir yang berbeda-beda. Namun, pendamping tetap berinisiatif untuk sering mengadakan pertemuan sebanyak satu kali dalam seminggu bersama dengan anggota kelompok untuk mengenal lebih dalam dan mempelajari kebutuhan para anggotanya, hingga menetapkan program kegiatan bersama.

Adapun yang diungkapkan pendamping yaitu:

"Ya, memang sih tidak mudah ya karena kan maklum ya mindset mereka kan beda-beda, pada intinya saya sebagai pendamping ya kita jalankan pertemuan dengan anggota juga merupakan usaha saya membangun kepercayaan mereka, biar pemikirannya tidak hanya ke bantuan pemerintah saja, tetapi juga usaha pada kegiatan kelompok" (N/Guru Paud/51) Pendamping KUBE/12-7-2020).

Selain itu, penjelasan dari anggota KUBE mengenai cara pendamping dalam membangun kepercayaan anggota kelompok sangat baik, dikarenakan sikap yang ramah dan aktif untuk mengumpulkan para anggota kelompok. Aktivitas yang dilakukan pendamping ditujukan dengan pencapaian dalam membangun konsensus. Peran tersebut merupakan peranan fasilitatif yang menstimulasi atau mendukung pengembangan masyarakat (Ife, 2013). Terciptanya kepercayaan dengan pendekatan yang dilakukan pendamping saat pertemuan kelompok bertujuan untuk menciptakan kesepakatan kegiatan KUBE sebagai bentuk keterampilan dalam membangun konsensus.

2) Memberikan penguatan dan edukasi.

Pemberian edukasi bertujuan untuk mendukung dan menstimulasi proses pembelajaran masyarakat juga pengaturan agenda. Pada prinsipnya community worker harus terus menerus mempelajari keterampilan baru, cara berpikir baru, dan cara berinteraksi dengan lingkungan sehingga bisa mengajarkan masyarakat bagaimana melakukan sesuatu yang baru (Ife, 2013). Dalam hal ini, pendamping KUBE Melati 3 berperan dalam menumbuhkan kesadaran, memberikan informasi dan pelatihan kepada anggota KUBE. Pendamping berperan aktif dalam memberikan informasi dan melatih para anggota KUBE terkait cara pengemasan produk makanan sebagai program KUBE Melati 3, pemasaran, dan juga cara mempublikasi produk mereka. Selain itu, pendamping selalu menginformasikan tentang bantuan yang diberikan pemerintah, proses penyaluran, kegiatan pemberian makanan tambahan (PMT), dan strategi dalam perlombaan antar kelompok KUBE antar provinsi.

3) Membangun kerjasama dengan sistem sumber.

Sistem sumber merupakan salah satu aset yang dapat membantu keberlanjutan penghidupan (sustainable livelihood) bagi komunats. 
Keberadaan sistem sumber yang mumpuni dapat membantu pengembangan KUBE Melati 3 tanpa bergantung pada sumber dana utama yaitu dana UEP. Pendamping berperan aktif dalam upaya membangun koneksi dengan sistem sumber yang ada. Saat ini yang lebih mudah diakses adalah dukungan dari pihak Dinas Sosial DKI Jakarta untuk melibatkan KUBE Melati 3 disetiap program kegiatan yang berkaitan dengan produktivitas kelompok KUBE, usaha mikro kecil dan menengah (UMKM), dan kegiatan lain yang terkait.

Peranan pendamping dalam membangun jaringan dengan Dinas Sosial DKI Jakarta merupakan peran representatif dengan keterampilan jejaring kerja dalam berinteraksi dengan badan-badan eksternal/internal demi kepentingan atau keuntungan masyarakat (Ife, 2013).

4) Melakukan publikasi kegiatan KUBE.

Kegiatan KUBE Melati 3 dipublikasikan oleh pendamping dalam bentuk informasi ke media sosial dengan konsep sosio preneur pada website dan media sosial lainnya. Pendamping mempublikasikan tentang produk makanan KUBE Melati 3, aktivitas penyaluran PMT, hingga dokumentasi tentang perlombaan KUBE berprestasi. Aktivitas publikasi merupakan peran representatif yang dilakukan oleh pendamping pada keterampilan media (Ife, 2013).

5) Melaksanakan pelaporan dan evaluasi kegiatan.

Setelah melaksanakan berbagai tugas dan tanggung jawab pendampingan KUBE, pendamping diharuskan untuk membuat pelaporan dan evaluasi kegiatan bersama anggota kelompok. Peran yang dilakukan merupakan peran teknik yang dikemukakan oleh Ife (2013) dengan tujuan pengumpulan dan analisa data, dan persentasi tulisan. Sebagaimana yang telah diungkapkan oleh pendamping yaitu:

"Kalau untuk laporan pendamping KUBE ya saya laporan biasanya ke Dinas Sosial nanti copy-annya ke kecamatan. Laporan tiap bulan untuk saya pendamping KUBE, tapi kalau untuk pelaporan keuangan itu intern KUBE Melati 3 aja. Misalnya ada anggota yang lapor ke saya tentang keuangan kelompok, kemudian saya buatkan pembukuannya dan memantau perkembangannya. Hingga saat ini belum ada masalah terkait pelaporan" (N/ Guru Paud/ 51/ Pendamping KUBE/ 12-7-2020).

Pernyataan dari pendamping menunjukkan bahwa, aktivitas pelaporan dan evaluasi merupakan kewajiban yang dilakukan setiap bulannya kepada Dinas Sosial dan Kecamatan untuk menilai aktivitas KUBE Melati 3 dalam memanfaatkan dana UEP dan upayaupaya pemberdayaan lainnya. Adapun pelaporan keuangan dan penggunaanya merupakan tanggung jawab bersama antara pendamping dan anggota kelompok sebagai sistem internal.

\section{KESIMPULAN}

Pemberdayaan merupakan suatu upaya dalam memperkuat sumberdaya dan partisipasi masyarakat untuk meningkatkan kapasitasnya dalam menentukan masa depan yang lebih baik. Upaya tersebut memiliki kekuatan (power) atau daya dari kelompok yang kurang beruntung. Hal 
ini merupakan daya dalam pilihan pribadi dan peluang hidup, daya atas kebutuhan, daya dalam gagasan, daya untuk memberikan perubahan sosial dan ekonomi, daya dalam mengakses sistem sumber, daya atas kegiatan ekonomi dan upaya lainnya yang bersifat produktif.

KUBE Melati 3 Provinsi DKI Jakarta telah melakukan upaya tersebut dalam bentuk sinergitas antara partisipasi anggota kelompoknya dan peranan dari pendamping KUBE.

Partisipasi KUBE Melati 3 digambarkan sebagai keterlibatan mental dan emosi, serta keterlibatan fisik dalam mewujudkan pemberdayaan. Partisipasi secara mental dan emosi dapat digambarkan sebagai berikut:

1. Upaya pembangunan lingkungan dan pembangunan diri sendiri melalui keterampilan usaha yang dimiliki masingmasing anggota dalam membentuk kelompok usaha yaitu KUBE Melati 3.

2. Memiliki sense of belongines yang mengharuskan kelompok untuk berpartisipasi pada program-program di Kelurahan dan Kecamatan dan kegiatan produktif lainnya untuk meningkatkan usaha kelompok.

3. Memiliki harapan untuk tetap mendapatkan bantuan usaha ekonomi produktif (UEP) denggan proses yang mudah dari pemerintah, dan dukungan dari swasta yang berupa investasi. Harapan lain yang menunjang adalah agar semakin banyak masyarakat yang memesan catering mereka dan menjadi kelompok tetap pengelola PMT di Kelurahan dan program lainnya di Kecamatan.
Selanjutnya, partissapi secara fisik dapat digambarkan sebagai berikut:

1. Anggota kelompok menunjukkan kolaborasi dan kontrol bersama dalam pengambilan keputusan. Mereka melakukan empowering process untuk memikirkan memecahkan masalah bersama, dan menumbuhkan rasa percaya diri pada pengambilan keputusan tersebut.

2. Menyumbangkan gagasan pemikiran pada suatu pertemuan secara musyawarah untuk merencanakan program dan kegiatan kelompok dalam pemberdayaan.

3. Membantu rutinitas kegiatan posbindu dan posyandu sebagai ibu kader dan mengelola pemberian makanan tambahan (PMT) pada kegiatan tersebut sebagai pemilik otonomi dalam menumbuhkan rasa tanggung jawab kelompok.

4. Menunjukkan keterampilan dan kemahiran usaha produk makanan/catering pada kegiatan bazar dan perlombaan.

5. Memanfaatkan aset finansial dalam bentuk iuran kas sebanyak Rp.5000,- di setiap anggota pada pertemuan kelompok untuk kepentingan kelompok.

Adapun pendamping KUBE dapat melakukan peranan sebagai community worker. Peranan tersebut antara lain adalah:

1. Peran fasilitatif pada keterampilan membangun konsensus dengan cara membangun kepercayaan anggota kelompok untuk memperoleh kesepakatan bersama pada suatu pertemuan kelompok. Pendamping mengarahkan dan menginisasi kelompok 
dalam membuat strategi pada aktivitas penyaluran produk usaha dan keterampilan KUBE Melati 3 dalam berbagai program di masyarakat.

2. Peran edukasional dengan cara mempelajari pola interaksi dan lingkungan sekitar, kemudian mengajarkan anggota kelompok untuk melakukan inovasi pada usaha kelompok. Termasuk diantaranya adalah mengajarkan strategi pembuatan dan pengemasan produk, pemasaran dan publikasi produk.

3. Peran representatif dengan cara mengakses sistem sumber dan publikasi media. Pendamping aktif dalam membangun koneksi khususnya pada pihak Kelurahan dan Kecamatan sehingga KUBE Melati 3 mendapatkan kepercayaan untuk mengelola program pemberian makanan tambahan (PMT) pada kegiatan posbindu dan posyandu. Dalam hal publikasi, pendamping melakukan keterampilan media untuk menginformasikan segala aktivitas KUBE pada sosial media.

4. Peran teknik dalam penulisan pelaporan kegiatan KUBE Melati 3 dan evaluasi kegiatan. Pelaporan dilakukan setiap akhir bulan yang ditujukan kepada Dinas Sosial dan Kecamatan. Adapun kegiatan evaluasi dilakukan bersama dengan anggota kelompok pada setiap pertemuan saat membahas kegiatan kelompok sebagai bentuk evaluasi proses. Evaluasi hasil dilakukan setelah kegiatan selesai.
Ahmad Imaduddin, S. H. (2016). Implementasi

Program Kelompok Usaha Bersama (KUBE) dalam Pemberdayaan Fakir Miskin Binaan Dinas Sosial Wilayah Kecamatan Samarinda Utara di Kota Samarinda. eJournal Administrative Reform, 351-362.

Azhari, S. (2015). Partisipasi Masyarakat dalam Program Kelompok Usaha Bersama (KUBE) di Kecamatan Teluk Bintan Tahun 2014.

Djunaedi, D. (2013). Implementasi Kebijakan Penanggulangan Kemiskinan Melalui Program Pemberdayaan Kelompok Usaha Bersama di Kabupaten Seruyan.Universitas Terbuka.

Dwiningrum, S. I. (2011). Desentralisasi dan Partisipasi Masyarakat dalam Pendidikan. Yogyakarta: Pustaka Pelajar. Faturochman, d. (2007). Membangun Gerakan Penanggulangan Kemiskinan Melalui Pemberdayaan Masyarakat. Yogyakarta: Pusat Studi Kependudukan dan Kebijakan Universitas Gadjah Mada.

Handayani, S. (2006). Perlibatan masyarakat Marginal dalam Perencanaan dan Pengangaran Partisipasi (Cetakan Pertama). Surakarta: Kompip Solo.

Hidayatulloh, S. Y. (2015). Kinerja Kelompok Usaha Bersama (KUBE) dalam Pengentasan Kemiskinan. Jurnal PKS, 163-180.

Huraerah, A. (2008). Pengorganisasian dan Pengembangan Masyarakat Model dan 
Strategi Pembangunan Berbasis

Kerakyatan. Bandung: Humaniora.

Huraerah, A. (2011). Pengorganisasian dan Pengembangan Masyarakat. Bandung: Humaniora.

Ibrahim Imron, M. S. (2014). Pemberdayaan Masyarakat Miskin Melalui Kelompok Usaha Bersama (Studi Pada Kelompok Usaha Bersama di Desa Dawuhan, Kec. Poncokusumo, Kab. Malang). Jurnal Administrasi Publik, 485-491.

Ife, J. (2013). Community Development: Community-Based Alternatives in an Age of Globalisation. Australia: French Forest: Pearson Education .

Indrika, R. (2013). Pemberdayaan Masyarakat Melalui Program Kelompok Usaha Bersama (KUBE) Tanjung dalam Meningkatkan Kualitas Hidup. Universitas Negeri Yogyakarta.

Mantiri, M. S. (2016). Implementasi Program Kelompok Usaha Bersama (KUBE) dalam Pemberdayaan Masyarakat di Kecamatan Tabukan Tengah Kabupaten Kepulauan Sangihe. Jurnal Eksekutif, 2.

Mikkelsen, B. (2005). Methods for Development Work and Research: A New Guide for Practitioners.2nd Ed. California: Sage Publication.

Muhammad Hidayat Nasmi, K. D. (2019). Pemberdayaan Masyarakat Miskin Melalui Kelompok Usaha Bersama (KUBE) di Kec. Bintan Timur oleh Dinas Sosial Kab. Bintan. Dialektika Publik, 2.
Mustafa, A. A. (2015). Efektivitas program Kelompok Usaha Bersama Fakir Miskin (KUBE-FM). Universitas Hasanuddin.

Ndraha, T. (1994). Manajemen Pemerintahan, Pembangunan dan Pembinaan Masyarakat (MP3M) di Lingkungan Departemen Dalam Negeri,IIP. Jakarta. Neuman, L. W. (2013). Metode Penelitian Sosial: Pendekatan Kualitatif dan Kuantitatif (Edina T. Sofia, Penerjemah). Jakarta: Indeks.

Permensos No. 2 Tahun 2019 tentang Bantuan Sosial Usaha Ekonomi Produktif (UEP) kepada Kelompok Usaha Bersama (KUBE) untuk Penanganan Fakir Miskin.

Pratiwi, A. (2014). Pemberdayaan Ekonomi Perempuan Melalui Program Kelompok USaha Bersama (Studi Deskriptif KUBE Lentera, Kelurahan Lenteng Agung). Universitas Indonesia.

Purnamasari, I. (2011). Partisipasi Masyarakat dalam Perencanaan Pembangunan $d i$ Kecamatan Cibadak Kabupaten Sukabumi. Jurnal Sosial Humaniora , 1.

Ripai, A. (2013). Partisipasi Masyarakat dalam Pembangunan di Kecamatan Bontomatene Kabupaten Kepulauan Selayar. Universitas Hasanuddin.

Tumbel, S. M. (2017). Partisipasi Masyarakat dalam Pengelolaan Dana Desa di Desa Tumaluntung Satu Kecamatan Tareran Kabupaten Minahasa Selatan.Jurnal Politico,1. 
Usmaniya, D. (2014). Partisipasi Masyarakat dalam Penyelenggaraan Program Pelaksanaan Kelompok Usaha Bersama (KUBE) di Kelurahan Dompak Kecamatan Bukit Bestari Kota Tanjungpinang Tahun 2013. Universitas Maritim Raja Ali Haji.

Wulandari, F. R. (2011). Peran Pekerja Sosial Masyarakat Kelompok Usaha Bersama dalam Pemberdayaan Keluarga Miskin di Desa Lebak Wangi Kecamatan Sepatan Timur Tangerang. UIN Syaif Hidayatullah Jakarta.

Yasin, H. (2015). Upaya Strategis Pemberdayaan Ekonomi Masyarakat Melalui Kelompok Usaha Bersama (KUBE). Jurnal Administrasi Publik, 1. 